\title{
Slow, but steady: dispersal of freshwater molluscs
}

\author{
Heike Kappes $\cdot$ Peter Haase
}

Received: 14 September 2010/ Accepted: 1 February 2011/Published online: 2 March 2011

(c) The Author(s) 2011. This article is published with open access at Springerlink.com

\begin{abstract}
Molluscs are the proverbial examples of slow movement. In this review, dispersal distances and speed were assessed from literature data. Active upstream movement can occur both individually and in groups; and depends on traits such as size, sex and reproductive status, and on external factors such as flow velocity, temperature, sediment structure, and food availability. The potential for active dispersal follows the sequence Pulmonata $\geq$ Prosobranchia $>$ Bivalvia, although data for Pulmonata originated from short-term experiments that likely overestimated dispersal capabilities. Active upstream movement may be 0.3 to $1.0 \mathrm{~km}$ per year for most snails and is probably well below $0.1 \mathrm{~km}$ per year for bivalves. Natural passive upstream dispersal increases the range 10-fold (snails) to 100-fold (bivalves), and anthropogenic vectors can increase upstream dispersal more than 100-fold (snails) to 1000 -fold (bivalves). Three $\mathrm{km}$ seems to be the maximal within-stream distance at which many species display regular population mixing, and at which re-colonisation or successful restoration can be expected within 3-10 years. Lateral dispersal between unconnected water bodies is passive and mostly known from observational reports, but potential distances depend on vectors, climate and geomorphology. In general, active dispersal seems insufficient to furnish a compensatory mechanism, e.g., for the rate of projected climate change. We provide an overview on
\end{abstract}

\section{H. Kappes $(\bowtie) \cdot$ P. Haase}

Department of Limnology and Conservation,

Senckenberg Research Institute and Natural History Museum,

Clamecystraße 12, 63571 Gelnhausen, Germany

e-mail: hekappes@senckenberg.de

\section{H. Kappes · P. Haase}

Biodiversity and Climate Research Centre (LOEWE BiK-F), Senckenberganlage 25, 60325 Frankfurt aM, Germany dispersal strategies in the light of applied issues. More rigorous field surveys and an integration of different approaches (such as mark-recapture, genetic) to quantify distances and probabilities of lateral dispersal are needed to predict species distributions across space and time.

Keywords Biological invasion - Dispersal . Global change $\cdot$ Mollusca $\cdot$ Species distribution modelling (SDM) $\cdot$ Vector

\section{Introduction}

The Mollusca provide proverbial examples for "sluggishness" and time-consuming movements "at a snail's pace". However, snails and mussels do disperse. Some invasive snails and mussels have even become notorious for their rapid spread, and invasive molluscs can be found in the marine, limnic and terrestrial realms. Molluscs thus provide a well-suited and relevant model group to study the role of active and passive dispersal in hololimnic macroinvertebrates.

Our review covers all freshwater species from both lotic and lentic habitats. However, many studies on dispersal have been performed in rivers, and some dispersal mechanisms such as drift apply only to riverine systems. Riverine taxa can display longitudinal dispersal by upstream or downstream movements within a stream network, or lateral dispersal to a neighbouring stream by movement across the terrestrial matrix. In contrast, lake-dwelling species mainly show lateral dispersal to neighbouring lakes.

Anthropogenic dispersal has allowed several freshwater molluscs to cross biogeographic boundaries. Some of these species, such as Potamopyrgus antipodarum (Gray) (Gastropoda: Hydrobiidae) or Corbicula fluminea (O.F. Müller) 
(Bivalvia: Corbiculidae), are highly invasive. Invasive species can spread at comparatively high velocities within catchments, but they also tend to cross regional watersheds. This spread contrasts with shrinking ranges of some indigenous species that display signs of population breakdowns (e.g., Neves et al. 1997; Kobialka et al. 2009). Knowledge of dispersal capabilities is thus important both for understanding (potential) invasiveness and for protecting populations of sensitive indigenous species. Moreover, knowledge of dispersal capabilities is needed for assessing re-colonisation speed in stream restoration projects. Also, knowledge of dispersal capabilities is essential for evaluating gene flow and future distribution ranges in species distribution modelling (SDM) under the framework of global change, as recently shown for Radix balthica (Lymnaeidae) (Cordellier and Pfenninger 2009).

Only a few reviews on dispersal include molluscs; even then, molluscs are treated only marginally (e.g., Bilton et al. 2001; Bohonak and Jenkins 2003; Holeck et al. 2004). More specific contributions and reviews on molluscs dealt with biogeographical aspects (Taylor 1988) and considered specific taxonomic groups (Mackie 1979; Karatayev et al. 2007) or special modes of dispersal such as aerial dispersal (Rees 1965; Wesselingh et al. 1999). To our knowledge, a compilation and comparison of dispersal distances and dispersal speeds, including results from genetic studies, has not yet been performed. We are well aware that additional records likely exist, especially in the so-called "grey literature". Nevertheless, we feel that this general review gives a good idea of average active and passive dispersal ability of aquatic molluscs and of some factors that govern it. We additionally analyse potential phylogenetic constraints or advantages in dispersal, and we indicate which aspects of freshwater mollusc dispersal need more research effort.

We address active and passive dispersal. Our focus is on upstream dispersal, as it occurs against setbacks from drift. Upstream dispersal thus provides an estimate of the minimal dispersal potential, or the minimal active invasion potential. We also give examples of passive dispersal, both downstream by drift and upstream by natural vectors such as fish, and by anthropogenic vectors such as ships. Finally, we address lateral dispersal by molluscs.

\section{Active dispersal}

Active dispersal of aquatic organisms can only occur in the aquatic environment. Active movement depends on traits such as the size, sex and reproductive status of individuals, and on external factors such as flow velocity, water temperature, sediment heterogeneity, and food availability.
Individual and group dispersal can both occur. Because of high natural heterogeneity and setbacks from drift, the potential distance that can be travelled by a species is most likely overrated by short-term experiments that usually were performed under laboratory conditions (Fig. 1). Taxonomic position likely affects dispersal capabilities. However, we observed a taxonomic bias in the approaches to assess dispersal velocity, with Pulmonata studied only rarely (Fig. 1, Table 1). We therefore included some of our own observations on pulmonates in order to fill this gap to some extent (Table 2).

\section{Crawling activity and rheotaxis}

Crawling activity and direction are essential for active dispersal. However, habitat use and morphological constraints influence crawling activity: potential activity is higher in the freely crawling Gastropoda than in the sedentary, sedimentburrowing Bivalvia (Fig. 1, Table 1). Indeed, among the Unionidae, Pseudanodonta complanata (Rossmässler) seemed to be stationary during a field survey in Finland performed during the reproductive season in June and August (Saarinen and Taskinen 2003). Mussels in the River Spree only moved towards the shore, whereas no significant upstream or downstream movement was detected (Schwalb and Pusch 2007). Similarly, Anodontoides ferussacianus (Lea) (Unionidae) and Sphaerium sp. (Sphaeriidae) moved

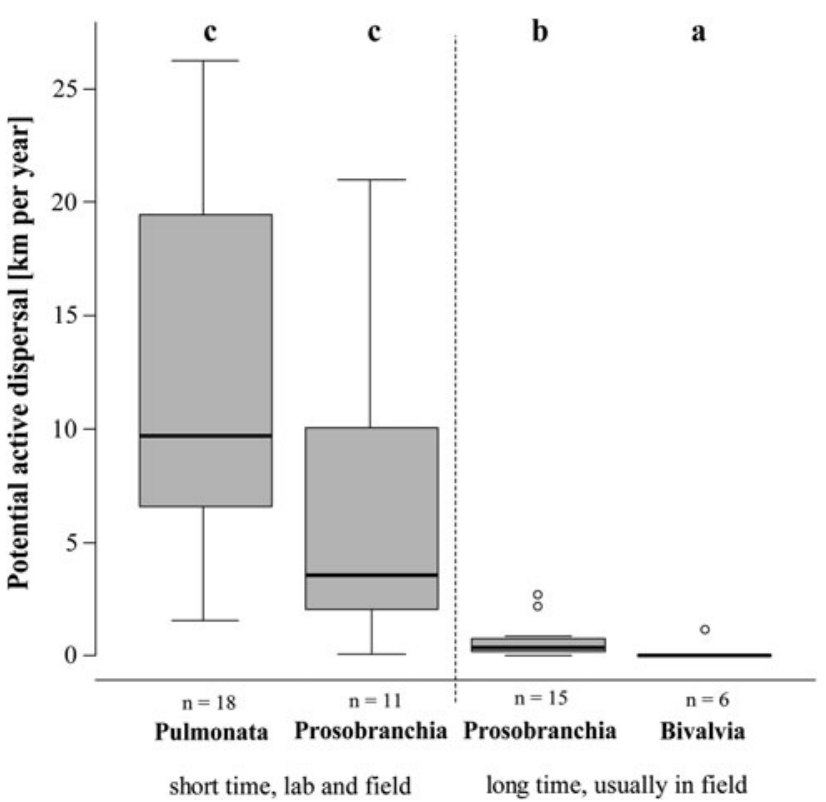

Fig. 1 Estimated maximal potential yearly active dispersal distance of molluscan taxonomic groups, presented for long (one week and more) and short (minutes to a few days) time intervals. Data points originate from sources in Table 1. To overcome the low availability of data on Pulmonata, we added some of our own data (see Table 2). Shared letters indicate a lack of significance using the Tukey HSD test on the log-transformed data. Small circles indicate outliers 
Table 1 Compilation of the (partially recalculated) active dispersal rates from the literature survey

\begin{tabular}{|c|c|c|c|c|c|c|}
\hline Species & Family & Sub-order & $\mathrm{m} 1$ & m 2 & Velocity $[\mathrm{m} / \mathrm{d}]$ & Source \\
\hline Corbicula sp. & Corbiculidae & Biv & in-stream & long & 3.20 & Voelz et al. (1998) \\
\hline Elliptio complanata & Unionidae & Biv & in-lake & long & 0.01 & Amyot and Downing (1998) \\
\hline Elliptio complanata & Unionidae & Biv & in-lake & long & 0.03 & Amyot and Downing (1998) \\
\hline Anodonta anatina & Unionidae & Biv & in-stream & long & 0.02 & Schwalb and Pusch (2007) \\
\hline Unio sp. & Unionidae & Biv & in-stream & long & 0.02 & Schwalb and Pusch (2007) \\
\hline Several species ${ }^{a}$ & Unionidae & Biv & lab, no current & long & 0.03 & Allen and Vaughn (2009) \\
\hline Pomacea paludosa & Ampullaridae & Pros & in-lake & long & 2.00 & Darby et al. (2002) \\
\hline Pomacea paludosa & Ampullaridae & Pros & in-lake & long & 6.00 & Darby et al. (2002) \\
\hline Potamopyrgus antipodarum & Hydrobidae & Pros & in-lake & long & 1.00 & Ribi (1986) \\
\hline Potamopyrgus antipodarum & Hydrobidae & Pros & in-stream & long & 0.66 & Adam (1942) \\
\hline Potamopyrgus antipodarum & Hydrobidae & Pros & in-stream & long & 1.20 & Haynes et al. (1985) \\
\hline Neritina punctulata & Neritidae & Pros & in-stream & long & 2.40 & Pyron and Covich (2003) \\
\hline Neritina punctulata & Neritidae & Pros & in-stream & long & 7.40 & Pyron and Covich (2003) \\
\hline Neritina punctulata & Neritidae & Pros & in-stream & long & 0.81 & Pyron and Covich (2003) \\
\hline Elimia sp. $<1 \mathrm{~cm}$ & Pleuroceridae & Pros & in-stream & long & 0.00 & Huryn and Denny (1997) \\
\hline Elimia $\mathrm{sp} .>1 \mathrm{~cm}$ & Pleuroceridae & Pros & in-stream & long & 2.20 & Huryn and Denny (1997) \\
\hline Leptoxis carinata & Pleuroceridae & Pros & in-stream & long & 0.02 & Stewart (2007) \\
\hline Leptoxis carinata & Pleuroceridae & Pros & in-stream & long & 0.25 & Stewart (2007) \\
\hline Leptoxis carinata & Pleuroceridae & Pros & in-stream & long & 0.84 & Stewart (2007) \\
\hline Leptoxis carinata & Pleuroceridae & Pros & in-stream & long & 0.18 & Stewart (2007) \\
\hline Viviparus ater & Viviparidae & Pros & in-lake & long & 1.00 & Ribi (1986) \\
\hline Bithynia tentaculata & Bithyniidae & Pros & in-lake & short & 2.28 & MacRae and Lepitzki (1994) \\
\hline Bithynia tentaculata & Bithyniidae & Pros & in-lake & short & 0.22 & MacRae and Lepitzki (1994) \\
\hline Potamopyrgus antipodarum & Hydrobidae & Pros & lab, current & short & 7.20 & Haynes et al. (1985) \\
\hline Tarebia granifera & Thiaridae & Pros & in-stream & short & 28.8 & Snider and Gilliam (2008) \\
\hline Tarebia granifera & Thiaridae & Pros & in-stream & short & 57.6 & Snider and Gilliam (2008) \\
\hline Tarebia granifera & Thiaridae & Pros & in-stream & short & 26.5 & Snider and Gilliam (2008) \\
\hline Tarebia granifera & Thiaridae & Pros & in-stream & short & 1.00 & Snider and Gilliam (2008) \\
\hline Tarebia granifera & Thiaridae & Pros & in-stream & short & 34.9 & Snider and Gilliam (2008) \\
\hline Viviparus ater & Viviparidae & Pros & in-lake & short & 18.9 & Ribi and Arter (1986) \\
\hline Viviparus ater & Viviparidae & Pros & in-lake & short & 9.80 & Ribi and Arter (1986) \\
\hline Campeloma decisum & Viviparidae & Pros & in-stream & short & 8.00 & Bovbjerg (1952) \\
\hline Physa or Radix & - & Pulm & lab, current & short & 43.0 & Hoffman et al. (2006) \\
\hline Physa or Radix & - & Pulm & lab, current & short & 72.0 & Hoffman et al. (2006) \\
\hline
\end{tabular}

Biv Bivalvia, Pros Prosobranchia, Pulm Pulmonata, $m$ methodological annotations

${ }^{a}$ Actinonaias ligamentina, Amblema plicata, Fusconaia flava, and Obliquaria reflexa

equally with or against the water current at flow velocities between 4 and $12 \mathrm{~cm} \mathrm{sec}^{-1}$, but more than $65 \%$ were indefinite in direction (Shelford 1914).

Individuals of Elliptio complanata (Lightfoot) moved up to $3 \mathrm{~cm} \mathrm{~d}^{-1}$, but mean distances exceeded $1 \mathrm{~cm} \mathrm{~d}^{-1}$ only during the spawning period (Amyot and Downing 1998). Allen and Vaughn (2009) found that the average movements of the North American species Actinonaias ligamentina (Lamarck), Amblema plicata (Say), Fusconaia flava (Rafinesque) and Obliquaria reflexa Rafinesque were in the range of 10 to $30 \mathrm{~cm}$ during the 11 days of an experiment, thus moving ca. $3 \mathrm{~cm} \mathrm{~d}^{-1}$. The average rate of movement of the European species Unio tumidus Philipsson, Unio pictorum (Linnaeus) and Anodonta anatina (Linnaeus) in the lowland River Spree (Germany) was only $11 \pm 15 \mathrm{~cm}$ per week, or $1.6 \mathrm{~cm} \mathrm{~d}^{-1}$, between May and October (Schwalb and Pusch 2007). Total distances can be roughly estimated from trails left in the sediment. Unio pictorum and A. anatina from lake populations left trails having an average length of up to ca. 1 meter or 2 meters, respectively, during June and August 1996 (Saarinen and Taskinen 2003). 
Table 2 Potential dispersal velocity, based on distances travelled in one minute (i.e., according to short-time measurements) on a plain surface without water current

\begin{tabular}{lllll}
\hline Species & Family & Shell size [mm] & Velocity [m/day] & $n$ \\
\hline Physa fontinalis & Physidae & 1.0 & 18.7 & 1 \\
Physa fontinalis & Physidae & $1.1 \pm 0.2$ & $11.9 \pm 6.5$ & 7 \\
Physa fontinalis & Physidae & $8.0 \pm 0.9$ & $19.7 \pm 20.8$ & 7 \\
Physa fontinalis & Physidae & 9.0 & 59.0 & 1 \\
Physella acuta & Physidae & $1.9 \pm 0.7$ & $18.0 \pm 23.3$ & 6 \\
Physella acuta & Physidae & 3.0 & 53.3 & 1 \\
Physella acuta & Physidae & 3.5 & 66.2 & 1 \\
Physella acuta & Physidae & $3.7 \pm 0.9$ & $34.6 \pm 26.1$ & 7 \\
Physella acuta & Physidae & 6.0 & 44.6 & 1 \\
Physella acuta & Physidae & $7.3 \pm 0.8$ & $23.0 \pm 17.8$ & 6 \\
Radix balthica & Lymnaeidae & $4.4 \pm 0.9$ & $6.6 \pm 8.4$ & 7 \\
Radix balthica & Lymnaeidae & 5.0 & 18.7 & 1 \\
Radix balthica & Lymnaeidae & 10.0 & 14.4 & 1 \\
Radix balthica & Lymnaeidae & $10.8 \pm 1.6$ & $4.3 \pm 5.1$ & 7 \\
Radix balthica & Lymnaeidae & 16.0 & 72.0 & 1 \\
Radix balthica & Lymnaeidae & $17.0 \pm 2.6$ & $29.8 \pm 30.1$ & 7 \\
\hline
\end{tabular}

$n$ is the number of individuals. Measurements were performed in the afternoon of June 28, 2010. Movement behaviour usually differed strongly between individuals of a given aquarium (size classes were reared separately) as indicated by the standard deviation. Food was offered ad libitum

Higher dispersal rates have been found for Viviparus ater (De Cristofori and Jan) (Viviparidae) and Potamopyrgus antipodarum (Hydrobiidae), with diffusion rates of approximately $1 \mathrm{~m}^{2} \mathrm{~d}^{-1}$ in Lake Zurich, Switzerland (Ribi 1986). Similarly, Bithynia tentaculata (Linnaeus) (Bithyniidae) showed no ontogenetic effect on movement rates in pools (MacRae and Lepitzki 1994). This species can move between 0.9 and $9.5 \mathrm{~cm} \mathrm{~h}^{-1}$ (MacRae and Lepitzki 1994), equivalent to a distance of up to $2.2 \mathrm{~m} \mathrm{~d}^{-1}$.

Significant upstream movements of gastropods have been found in at least 10 families (Huryn and Denny 1997). The most intriguing behaviour is that of freshwater nerites (Neritidae). Neritidae in tropical and subtropical streams display gregarious upstream migrations worldwide (Blanco and Scatena 2005, and references therein). This behaviour was first described for the tropical snail Neritina latissima Broderip in a coastal stream in Costa Rica, where the upstream migration of juveniles covered a stretch of stream that exceeded $1 \mathrm{~km}$ in length (Schneider and Frost 1986). Here, the colonisation cycle hypothesis (Müller 1954) seems applicable, as the post-metamorphosis life stage clearly compensates for downstream drift of the premetamorphosis life stage by upstream movement. However, the same phenomenon was observed in the directly developing Cochliopina tryoniana (Pilsbry) (Hydrobiidae) from the same coastal stream (Schneider and Lyons 1993).
The size distribution of migrating and stationary snails suggests that the migration takes more than one year for $N$. latissima and probably less than one year for $C$. tryoniana (Schneider and Lyons 1993).

In experiments, some specimens of the highly invasive Potamopyrgus antipodarum (Hydrobiidae) crawled $15 \mathrm{~cm}$ upstream in $30 \mathrm{~min}$., equal to a hypothetical maximal spread of $7.2 \mathrm{~m} \mathrm{~d}^{-1}$, or $2.6 \mathrm{~km} \mathrm{yr}^{-1}$ (Haynes et al. 1985). Distances were lower under field conditions. Haynes et al. (1985) tested the dispersal of $P$. antipodarum in the River Avon at a water current of about $17 \mathrm{~cm} \mathrm{sec}^{-1}$ and found that on average it showed a positive rheotaxis. Two individuals moved upstream at a velocity of $1.1-1.2 \mathrm{~m} \mathrm{~d}^{-1}$, whereas two individuals found furthest downstream from the release point were displaced 65 to $71 \mathrm{~cm}$ within 24 hours. At a longer time scale, $P$. antipodarum was found to actively move $60 \mathrm{~m}$ upstream in three months (Adam 1942), equal to average movement of $66 \mathrm{~cm} \mathrm{~d}^{-1}$.

Responses to water current velocity

Rheotactic behaviour varies among species and also among streams and seasons. Part of this spatiotemporal variation is attributable to differences in runoff regimes. Upstream migration can occur as a post-flood compensation response, as found in Neritina virginea (Linnaeus) (Blanco and Scatena 2005). Maximum upstream movement of Neritina punctulata Lamarck was $2.4 \mathrm{~m} \mathrm{~d}^{-1}$ following marking in August when the discharge was stable for about two weeks, and $7.4 \mathrm{~m} \mathrm{~d}^{-1}$ in May when the discharge was strongly fluctuating throughout the study period (Pyron and Covich 2003).

Individuals also respond directly to current velocity. Hoffman et al. (2006) studied the response of a pulmonate snail to water flow (called Physa sp. (Physidae) throughout the text, but a photograph from the authors' Fig. 1 shows a lymnaeid, probably Radix sp.). The snail moved at a speed exceeding $3 \mathrm{~cm}$ and $5 \mathrm{~cm} \mathrm{~min}{ }^{-1}$ at low and high current velocities, respectively. At high water velocities, responses of burrowing and nonburrowing species differ, as these species do either avoid high water velocities or face the risk of drifting. Goniobasis livescens (Menke) (Pleuroceridae) and Campeloma subsolidum (Anthony) (Viviparidae) generally move against the water current at velocities between 4 and $12 \mathrm{~cm} \mathrm{sec}^{-1}$ (Shelford 1914). The riffle-inhabiting $G$. livescens maintains positive rheotaxis, whereas the pool-living $C$. subsolidum becomes inactive at water velocities of 16-20 cm sec ${ }^{-1}$ (Shelford 1914). Similarly, the activity of Viviparus malleatus Reeve (Viviparidae) may decline with increasing current in streams (Hutchinson 1947). At strong water flows between 16 and $20 \mathrm{~cm} \mathrm{sec}^{-1}$, activity levels of Anodontoides ferussacianus and Sphaerium sp. declined to zero (Shelford 1914), and Sphaerium 
burrowed when subjected to a water current. Similarly, Potamopyrgus antipodarum tends to burrow in sediments at high current velocities (Holomuzki and Biggs 1999).

Role of the sediment and additional stimuli

Rheotactic behaviour and net movement can be influenced by sediment structure. Populations of Leptoxis carinata (Bruguiere) (Pleuroceridae) moved upstream at an average of $0.12 \mathrm{~m} \mathrm{~d}^{-1}$ (max. $0.18 \mathrm{~m} \mathrm{~d}^{-1}$ ) on rocky substrate, and $0.25 \mathrm{~m} \mathrm{~d}^{-1}$ (max. $0.84 \mathrm{~m} \mathrm{~d}^{-1}$ ) on sandy substrate (Stewart 2007). Hoffman et al. (2006) found that surface smoothness resulted in an increased net upstream move, and that the positive relationship between snail speed and water velocity did not occur on the more structured surface.

An ontogenetic effect was observed in free-ranging Elimia (Pleuroceridae). Only larger individuals showed upstream movement with a maximum rate exceeding $200 \mathrm{~m}$ over a 3-month period, or $2.2 \mathrm{~m} \mathrm{~d}^{-1}$, whereas small individuals below $1 \mathrm{~cm}$ shell size were stationary (Huryn and Denny 1997). This apparent immobility of small individuals probably results from their ability to hide in the sediment, and it may have been influenced by additional stimuli. Size differences in the movement behaviour of Tarebia granifera (Lamarck) (Thiaridae) decreased with food availability: At high food availability, individuals of all size classes moved upstream together (Snider and Gillam 2008). The species easily reached velocities of $2 \mathrm{~m} \mathrm{~h}^{-1}$, or $48 \mathrm{~m} \mathrm{~d}^{-1}$.

Other external and intrinsic factors also were reported to affect dispersal rates. For instance, increased temperatures resulted in increased movement rates in Bithynia tentaculata (MacRae and Lepitzki 1994). Moreover, differences in activity between sexes were shown for Viviparus ater (Ribi and Arter 1986). In this species, the maximum movement distance was $18.9 \mathrm{~m} \mathrm{~d}^{-1}$ for males, and $9.8 \mathrm{~m} \mathrm{~d}^{-1}$ for females.

To sum up, a taxonomic bias in the approaches to assessment of dispersal velocity limits straightforward interpretation of the data. Active dispersal of smaller mussels and pill clams (Sphaeriidae) still needs to be assessed. Nevertheless, it seems reasonable to assume that the potential active dispersal values range between $300 \mathrm{~m}$ and $1 \mathrm{~km} \mathrm{yr}^{-1}$ for most snail taxa, whereas $100 \mathrm{~m} \mathrm{yr}^{-1}$ may rarely be exceeded by (most) bivalves.

\section{Passive dispersal}

Reports on invasions by freshwater molluscs show that active dispersal is only important at the local scale. The high velocity of both downstream and upstream spread after colonisation (IKSR 2002, Leuven et al. 2009) indicates that freshwater molluscs, like other invading taxa, readily use mechanisms other than active movement. Passive dispersal can be aquatic, i.e., within a stream, or extraaquatic when the individuals cross catchments. Passive longitudinal dispersal may be directed downstream (by drift or on vectors) or upstream (by vectors). Vectors for instream passive dispersal may be natural (fish) or anthropogenic (ships).

Passive aquatic dispersal

\section{Larval downstream drift}

Dispersal often is limited to specific life stages. Passive dispersal by planktonic larvae is common in the marine realm but not in freshwater environments. Larval drift has been reported mainly from freshwater representatives of predominantly marine families, such as the Neritidae and Mytilidae, but also in the Dreissenidae, a family that has evolved comparatively recently (Morton 1970). Especially in riverine systems, larvae may be washed downstream to unsuitable zones. Later in the life cycle, the juveniles need to compensate for drift. One of the few examples of larval planktonic drift in freshwater systems is Neritina latissima. This species was discussed above in the context of positive rheotaxis.

However, passive dispersal by planktonic larvae also occurs in some sedentary species. Passive dispersal of planktonic larvae is regarded as the primary longitudinal dispersal mechanism of Dreissenidae, such as Dreissena, Congeria and Mytilopsis (Carlton 1993; Pathy and Mackie 1993; Gelembiuk et al. 2006), and Mytilidae such as Limnoperna (Karatayev et al. 2007). The duration of the larval stage of Dreissena polymorpha (Pallas) lasts from a few days to a few weeks (Sprung 1993). During this time span, larvae are prone to drift displacement to unsuitable habitats or are easily transported in ballast water over long distances. For example, the population genetic structure of the invasive Dreissena bugensis Andrusov in the Volga River indicates multiple long-distance dispersal events (Therriault et al. 2005).

Because of the drift-prone planktonic stage, lake populations of Dreissena are considered to be an important source of recruitment in lake-outlet streams (Cleven and Frenzel 1993; Bobeldyk et al. 2005). However, larval mortality before and during settlement can be high (Sprung 1989). Lucy et al. (2008) observed that most recruitment of D. polymorpha in lake outlet rivers occurred in the first $2 \mathrm{~km}$ downstream from the lakes.

\section{Post-larval downstream drift}

Juveniles and adults can also use the water current for passive downstream drift. In all likelihood, this is the most 
common dispersal mechanism. Some species even show specific behavioural adaptations. The excretion of a single long byssus or a mucous thread to increase drag forces and facilitate passive dispersal during the post-larval phase has been reported from small bivalve specimens (Sigurdsson et al. 1976; Prezant and Chalermwat 1984; Dubois 1995). At a later stage, byssal attachments such as those of Dreissena may break and allow the mussels to relocate themselves (Ackerman et al. 1994).

Rafting on floating materials, including those from lake outlets, is another mechanism producing downstream drift. For example, an average daily influx of $2620 \pm 86$ adult Dreissena on floating macrophytes occurred in Christiana Creek, southwest Michigan (Horvath and Lamberti 1997). The authors observed that Vallisneria americana Michaux accounted for $60 \%$ of floating plant biomass, but that for morphological reasons it carried $90 \%$ of the Dreissena. On average, adult Dreissena rafted with Vallisneria americana for $333 \mathrm{~m}$, but average distance varied between 260 and $430 \mathrm{~m}$ when discharge was 2.8 and $3.6 \mathrm{~m}^{3} \mathrm{sec}^{-1}$, respectively (Horvath and Lamberti 1997). Ten of the 250 plants that were monitored floated for more than 800 meters (Horvath and Lamberti 1997). Likewise, the snail Potamopyrgus antipodarum often drifts along with floating plant material (Ribi 1986). Another example of downstream drift in gastropods is the Bliss Rapids snail, Taylorconcha serpenticola Hershler et al. (Hydrobiidae). This species showed less population structure in the central Snake River than in its spring tributaries (Liu and Hershler 2009). The authors concluded that this pattern is related to downstream drift that can occasionally overcome barriers such as dams.

\section{Longitudinal dispersal with fish}

Fish and birds are natural vectors that can enhance longitudinal dispersal. Birds are also involved in lateral dispersal between systems and will therefore be discussed later. Two mechanisms of longitudinal transport by fish are possible: fish may ingest molluscs, or the molluscs may actively attach to the fish vector.

The strategy of actively attaching to fish is realised, for example, in the parasitic stage of the life cycle of large mussels. This strategy allows long-distance dispersal both with and against the water current. In combination with other life-history traits such as high propagule pressure, large size and long life, large freshwater mussels such as Unionidae and Margaritiferidae have a high potential for invasiveness, that is, dispersal (Statzner et al. 2008). Bivalves such as Amblema plicata (Unionidae) have a comparatively weak population structure that indicates a large effective population size and/or high dispersal (Elderkin et al. 2007). Potential host fishes of A. plicata such as smallmouth bass Micropterus dolomeiu Lacepède (Centrarchidae) move up to $75 \mathrm{~km}$ (Lyons and Kanehl 2002). River fragmentation by dams for example affects the migration of host fishes (Watters 1996; Dean et al. 2002, and references therein) and thus threatens Unionidae because it reduces both habitat quality and dispersal.

The mechanism of dispersal by fish via ingestion and defecation has been reported for several mollusc taxa. This internal transport can occur in some freshwater fishes such as Coregonus pidschian (Gmelin) and C. nasus (Pallas) (Coregonidae) (Brown 2007) that ingested freshwater snails of the family Valvatidae (identified species: Valvata sincera Say) and pill clams (identified species: Pisidium idahoensis Roper) in high numbers, and many individuals survived (Brown 2007). The two fishes also ingested Lymnaeidae (identified species: Lymnaea atkaensis Dall), but only one individual was found alive (Brown 2007). Bondesen and Kaiser (1949) report that Potamopyrgus antipodarum can endure gut passage in Salmo trutta Linnaeus (Salmonidae) or Perca fluviatilis Linnaeus (Percidae). Haynes et al. (1985) experimentally tested the viability of $P$. antipodarum following gut passage in $\mathrm{On}$ corhynchus mykiss (Walbaum) (Salmonidae). The authors found that the species can survive six hours in rainbow trout guts, and that the snails often release offspring within 24 hours following gut passage. A laboratory experiment with the marine snail Hydrobia spp. (Hydrobiidae) consumed by juvenile Platichthys flesus (Linnaeus) (Pleuronectidae) at different temperatures revealed that the snails had survival rates between 46 to $92 \%$ (Aarnio and Bonsdorff 1997). Bivalves and Prosobranchia, which can seal the aperture of the shell with the operculum, are thus more likely to survive the gut conditions in fish and to be spread than are freshwater Pulmonata. Nevertheless, the distances of longitudinal transport in fishes depend on fish movement between ingestion and defecation. This factor still needs to be quantified.

Indirect evidence about postingestion dispersal distances comes from studies on invaders and genetic population structuring. Voelz et al. (1998) assume that fish were involved in the upstream movement of Corbicula that occurred at an average of $1.2 \mathrm{~km} \mathrm{yr}^{-1}$, equalling about $3.2 \mathrm{~m} \mathrm{~d}^{-1}$, in a protected area in South Carolina. The snail Valvata utahensis Call (Valvatidae) showed no significant population structure at a scale of $3 \mathrm{~km}$, whereas it displayed isolation-by-distance unrelated to connectivity at larger scales (Miller et al. 2006). The authors argue that the pattern possibly originates from the combined effects of different modes of dispersal, such as active upstream movement, passive downstream drift, and accidental transport by vectors. Indeed, naturally occurring passive longitudinal dispersal probably increases the velocity of upstream movement of snails 10-fold (Fig. 2). Another genetic survey 
Longitudinal, upstream dispersal distances per year

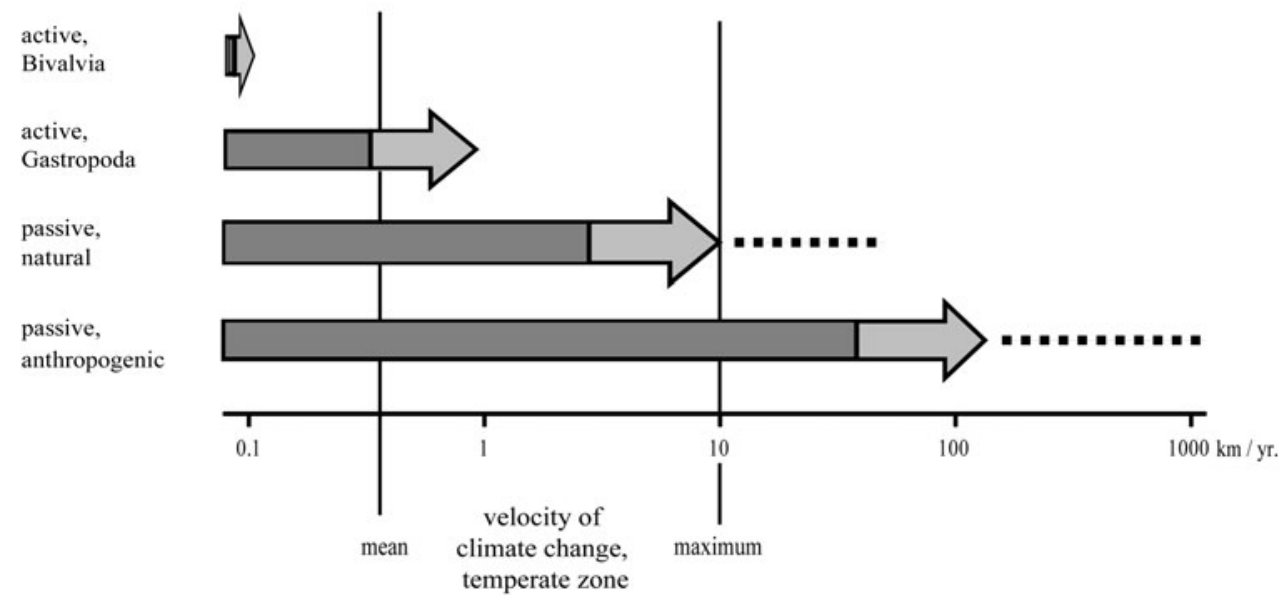

Fig. 2 Summary of annual distances that can be travelled upstream by freshwater molluscs with high (dark grey), moderate (light grey) and low (dotted lines) probability, either actively or by means of passive transport with natural or anthropogenic vectors. We acknowledge that these results are preliminary: the data base is relatively

furnished evidence for a rather restricted longitudinal exchange that may also be affected by landscape characteristics (Hughes 2007). Because active movements can be enhanced by passive drift, it may be assumed that potential downstream dispersal distances are rarely limited. However, more genetic studies are needed to assess the distances over which population mixing can take place.

\section{Anthropogenic longitudinal dispersal}

Attachment to vectors is highly effective when it involves fast-moving anthropogenic vectors. These vectors can travel along artificial waterways and thus further enhance dispersal by establishing longitudinal connectedness. Attachment via byssus threads typically occurs in the Dreissenidae and Mytilidae. A drydock survey revealed that a large proportion of the ships that reach the upper Rhine River from distant locations such as the Danube basin carry both attached $D$. polymorpha and the recent invader $D$. bugensis (Mayer et al. 2009). Once a new catchment has been entered, dispersal rates can be as high as $199 \mathrm{~km} \mathrm{yr}^{-1}$ or $276 \mathrm{~km} \mathrm{yr}^{-1}$, as was observed during the invasion of European waterways by Dreissena polymorpha and Corbicula fluminea, respectively (Leuven et al. 2009). However, field observations on spread may be deceptive if invaders can be confused with resident species, as is the case for the Dreissenidae. For example, field surveys in the Volga River basin suggested that Dreissena bugensis was introduced to the middle reach somewhat before 1992 and thereafter spread quickly over distances of several hundred $\mathrm{km}$, both upstream and downstream (Orlova et al. 2004). In contrast, a genetic survey on the same populations small, and not much is known about probabilities for the different taxonomic groups. The mean and maximum velocity of climate change in the temperate zone under the A1B emissions scenario (from Loarie 2009) is given for comparison

indicates multiple long-range introductions (Therriault et al. 2005). A revision of archived material revealed that at least three locations of the lower stretch were already settled in the early 1980 s, but that the shells were misidentified as $D$. polymorpha (Zhulidov et al. 2005).

Attachment of juveniles to floating material or to other vectors via a mucous thread has been found for Corbicula (Dubois 1995). As a result, Corbicula rapidly spreads in rivers with ship traffic. For example, Corbicula fluminea was first noted in the Mittellandkanal waterway in Germany close to its connection to the Elbe River in 1994 (Grabow and Martens 1995). By 1999, it had crossed the border to the Czech Republic (Beran 2006a, and references therein); i.e., it dispersed at least $340 \mathrm{~km}$ upstream within six years (about $57 \mathrm{~km} \mathrm{yr}^{-1}$, or $155 \mathrm{~m} \mathrm{~d}^{-1}$ ). Between 1999 and 2003, upstream dispersal slowed down, but the upper distribution border in the Elbe River moved upstream for another $83 \mathrm{~km}$ (on average $17 \mathrm{~km} \mathrm{yr}^{-1}$, or $45 \mathrm{~m} \mathrm{~d}^{-1}$ ) (Beran 2006a).

Passive dispersal associated with anthropogenic vectors such as ships can easily exceed active dispersal by as much as 100-fold (snails) to 1000-fold (bivalves), i.e., successful passive upstream dispersal readily occurs across (average) distances of $30-100 \mathrm{~km} \mathrm{yr}^{-1}$ (Fig. 2). Exceptions can occur in taxa such as Dreissena that can attach rather firmly to ships and thus disperse even further up- and downstream in shorter time intervals.

Passive extra-aquatic dispersal

Dispersal to unconnected habitats is also referred to as lateral dispersal, and lateral dispersal usually is extra- 
aquatic via terrestrial or aerial vectors that overcome the lack of physical connectedness. Thus, the pattern of dispersal often seems to be best described as a kind of passive jump dispersal involving long-range events over the borders of catchments (Wilson et al. 1999). There are many examples of passive lateral dispersal, and it is well known that molluscs can be transported by biotic vectors such as insects, birds, mammals (including man) and by abiotic vectors such as tornadoes (Rees 1965 and references therein; Johnson and Carlton 1996; Wilson et al. 1999, Green and Figuerola 2005 and references therein). During recent millennia, lateral dispersal also occurred along anthropogenic trade routes. Many aquatic molluscs have profited from human activities such as aquarium trade (Madsen and Frandsen 1989), trade in wetland vegetation (Beran 2006b), and transport by ships (Holeck et al. 2004). The deliberate or unintended transport of individuals has significantly accelerated the dispersal rates and has even globalised the distribution of several mollusc species during recent centuries (Madsen and Frandsen 1989; Rahel 2002; Holeck et al. 2004; Gutiérrez-Gregoric and Vogler 2010).

\section{Constraints on extra-aquatic dispersal}

The effectiveness of transport by extra-aquatic vectors is constrained by environmental factors that differ between the aquatic and terrestrial realm. Some factors affect the disperser, whereas others affect the vector. Climate influences the distances that can be travelled, as temperature and humidity have an effect on extra-aquatic survival times. Overland dispersal distances thus probably differ between seasons. For example, relocation of endangered mussels should be performed in cooler seasons to reduce mortality, as was found for the North American unionid Amblema plicata (Waller et al. 1995) and the South American hyriid Diplodon chilensis (Gray) (Peredo et al. 2006). Half of air-exposed Corbicula specimens survive 10 to 14 days at $15^{\circ} \mathrm{C}$, but only 3 days at $25^{\circ} \mathrm{C}$, or 1 day at $35^{\circ} \mathrm{C}$ (Byrne et al. 1988). Ricciardi et al. (1995) found that 73.3 and $40.0 \%$ of air-exposed large-sized individuals of Dreissena polymorpha and $D$. bugensis, respectively, survive for 10 days at $10^{\circ} \mathrm{C}$ and $95 \%$ $\mathrm{RH}$. Both species can disperse overland in summer $\left(20^{\circ} \mathrm{C}\right.$, $50 \% \mathrm{RH}$ ), so long as air exposure does not exceed three days (Ricciardi et al. 1995).

Short or circumvented phases of extra-aquatic transport thus cause the highly successful lateral spread that involves humans. Ballast water is considered to be the main route of introduction and subsequent spread of invaders such as $D$. bugensis (bij de Vaate 2010). Examples such as the introduction of the freshwater snail Potamopyrgus antipodarum (Hydrobiidae) from northern New Zealand to the UK (Städler et al. 2005) via ships over a distance of more than
$18,200 \mathrm{~km}$ underline the importance of ballast water transport for dispersal of aquatic organisms.

Also, vector behaviour and habitat preferences influence lateral dispersal patterns. The geomorphology of the landscape modifies passive dispersal capabilities. Lateral dispersal seems easier in the lowlands than in mountainous upstream systems (Hughes 2007), probably because mountainous terrain interacts with the movements of vectors and the dispersers must therefore remain longer on the vector before reaching a suitable habitat. Terrestrial vectors probably only act at a regional scale, whereas aerial vectors and anthropogenic aid offer basically unlimited opportunities for dispersal.

\section{Transport by terrestrial vectors}

Molluscs that live in shallow waters are likely to achieve contact with potential terrestrial vectors. These molluscs may display some behaviour that results in active attachment, or they may be accidentally transported along with substrate such as mud. Active attachment has been reported from some bivalves, including Unio. For example, these organisms sometimes appear actively involved in attachment to the hooks of anglers (Darwin 1882). Observations on dispersal capacities of small-sized Sphaeriidae (e.g., the genera Sphaerium, Musculium, Pisidium) are usually limited to lateral dispersal between isolated water bodies (Maguire Jr. 1963). Pond-dwelling amphibians such as newts and salamanders (Darwin 1882; Davis and Gilhen 1982), frogs (Darwin 1882) or toads (e.g., Kwet 1995) can carry Sphaeriidae on their toes. The attachment of bivalves is more common where clam densities are high (Wood et al. 2008). Attachment by bivalves usually damages the toes of the amphibians or birds, or the legs of insects (Darwin 1882; Green and Figuerola 2005; Wood et al. 2008). Often, the toes of the amphibians fall off and the clam is released (Wood et al. 2008). Yet, amphibians are only involved in dispersal on a local scale.

Transport in mud on European wild boar (Sus scrofa) has been proposed as a dispersal mechanism for the spring snail Bythinella dunkeri (Frauenfeld) (Hydrobiidae) that is endemic in parts of the German lower mountain ranges (Groh and Fuchs 1988). Similar mechanisms may apply to other spring snails. Worthington Wilmer et al. (2008) found for the Australian spring snail Fonscochlea accepta Ponder et al. (Hydrobiidae) that dispersal occurs at two scales: $\leq 300 \mathrm{~m}$ via active movement through habitat connections, or $\geq 3 \mathrm{~km}$ via some animal vector.

Anthropogenic terrestrial transport of molluscs is common. For example, lateral dispersal patterns of Dreissena in lakes in Wisconsin were more closely predicted by patterns of recreational boater activity than by a simple diffusion model (Buchan and Padilla 1999). The 
probability of successful lateral colonisation by Dreissena thus increases disproportionally with habitat size, so that unconnected lakes over 100 ha face an increased risk of invasion (Strayer 1991; Karataev and Burlakova 1995; Kraft and Johnson 2000). In contrast, naturally occurring lateral dispersal of Dreissena tends to be uncommon (Johnson and Carlton 1996, and references therein).

\section{Transport by aerial vectors}

Aerial dispersal can be completely accidental, such as in the case of tornadoes (Rees 1965 and references therein), or it may be preceded by an attachment to a winged vector such as large insects or birds. Among the large insects are the predaceous diving beetles (Dytiscidae), considered to be good dispersers (Darwin 1882). Species such as Sphaerium corneum (Linnaeus) (Sphaeriidae) have been observed to be attached for up to six days on legs of $D y$ tiscus marginalis (Linnaeus) (Darwin 1882). The snails Laevapex fuscus (Adams) and Ferrissia parallelus (Haldemann) have been found on the wings of "Dinutes" (invalid genus name, probably Dineutus, Gyrinidae) and Dytiscus (Dytiscidae), respectively (Johnson 1904).

Attachment to birds strongly enhances the dispersal range of molluscs. The presence and density of migratory birds significantly influences the distribution and diversity of wetland invertebrates (Green and Figuerola 2005 and references therein). The mechanisms related to mollusc dispersal are internal and external transport. Internal transport has been reported only rarely. Juvenile Sphaeriidae can survive ingestion by diving ducks (Mackie 1979). Similarly, a small proportion of snail eggs can survive gut passage in the waterfowl Anas platyrhynchos Linnaeus and Charadrius vociferus Linnaeus (Malone 1965). They can thus be transported across watersheds. Considerable evidence exists for external transport. Roscoe (1955) found immature individuals of the genera Physa, Lymnaea and Helisoma attached to the feathers of a Whitefaced Glossy Ibis (Plegadis mexicana (Gmelin)) in Utah. The potential duration of external transport of snails is 12-20 h (Darwin 1859, chapter XIII), or about $10 \mathrm{~km}$, as estimated from experiments with simulated flights with juveniles of the lymnaeids Lymnaea stagnalis (Linnaeus) and Stagnicola elodes (Say) and the planorbid Helisoma trivolvis (Say) (Boag 1986). A specimen of Elliptio complanata (Lightfoot) (Unionidae) was found attached to a toe of the duck Anas discors Linnaeus (Anatidae) (Darwin 1878).

Rare instances of long-distance dispersal with successful colonisation of the new habitat show that this phenomenon can occur over "unlimited" distances. Terrestrial snails of the genus Balea furnish an extreme example. Possibly, birds have spread these snails back and forth across the mid
Atlantic from island to island over distances of ca. $9000 \mathrm{~km}$ (Gittenberger et al. 2006). Some aquatic molluscs have also colonised these islands, however. Nevertheless, successful establishment after extreme but natural longdistance transport, e.g., to the Hawaiian Islands, probably only occurs at a frequency of 1-4 events per million years per site (e.g., Cowie and Holland 2006).

\section{Dispersal put into practice}

The integration of dispersal strategies and capacities may be useful in applications. Such integration can, for example, be implemented in generalised metrics in order to assess local or regional capacities for re-colonisation that can translate into restoration success, to compile a list of species expected to colonise new habitats within a given time scale, or to support predictions of connectivity in landscape planning. This approach might also be helpful when integrated in species distribution modelling (SDM) to predict climate-change driven shifts in species ranges.

However, assessment and quantification of dispersal capability are difficult because the hypothetical dispersal capability may not reflect actual dispersal (Hughes 2007). Because dispersal can most easily be tracked in invasive species, more is known about the dispersal capability of invasive species than that of native species. Additionally, there can be large intraspecific variation in dispersal (Stevens et al. 2010). We thus used general patterns on interrelations of habitat use and morphology with dispersal processes in a simplified classification scheme derived from the Euro-limpacs database (Euro-limpacs Consortium 2009). The Euro-limpacs database has free web access and provides autecological data for all freshwater taxa of Europe. So far, this database does not include entries on dissemination strategies and dispersal capacities of the Mollusca. Two main pathways for dispersal were proposed in the Euro-limpacs database, namely aquatic and aerial. We added another pathway, namely "terrestrial", for species that can be dispersed by terrestrial stages of amphibians or by wild boar. All pathways were subdivided into active and passive dispersal. The result was a total of six categories (Table 3 ).

Based on generalisations from our review, it is possible to assign dispersal strategies to taxa that have not been studied so far, but that share morphological and ecological traits with species mentioned above. Passive transport in water is a universal means of dispersal. Nevertheless, some of the categories generally do not apply. Aquatic molluscs do not actively move through terrestrial habitats, terrestrial species do not actively disperse through water, and molluses do not fly. 
Table 3 Dissemination strategies and potential dispersal capacities for freshwater molluscs from Germany, extrapolated from the data reported in the review

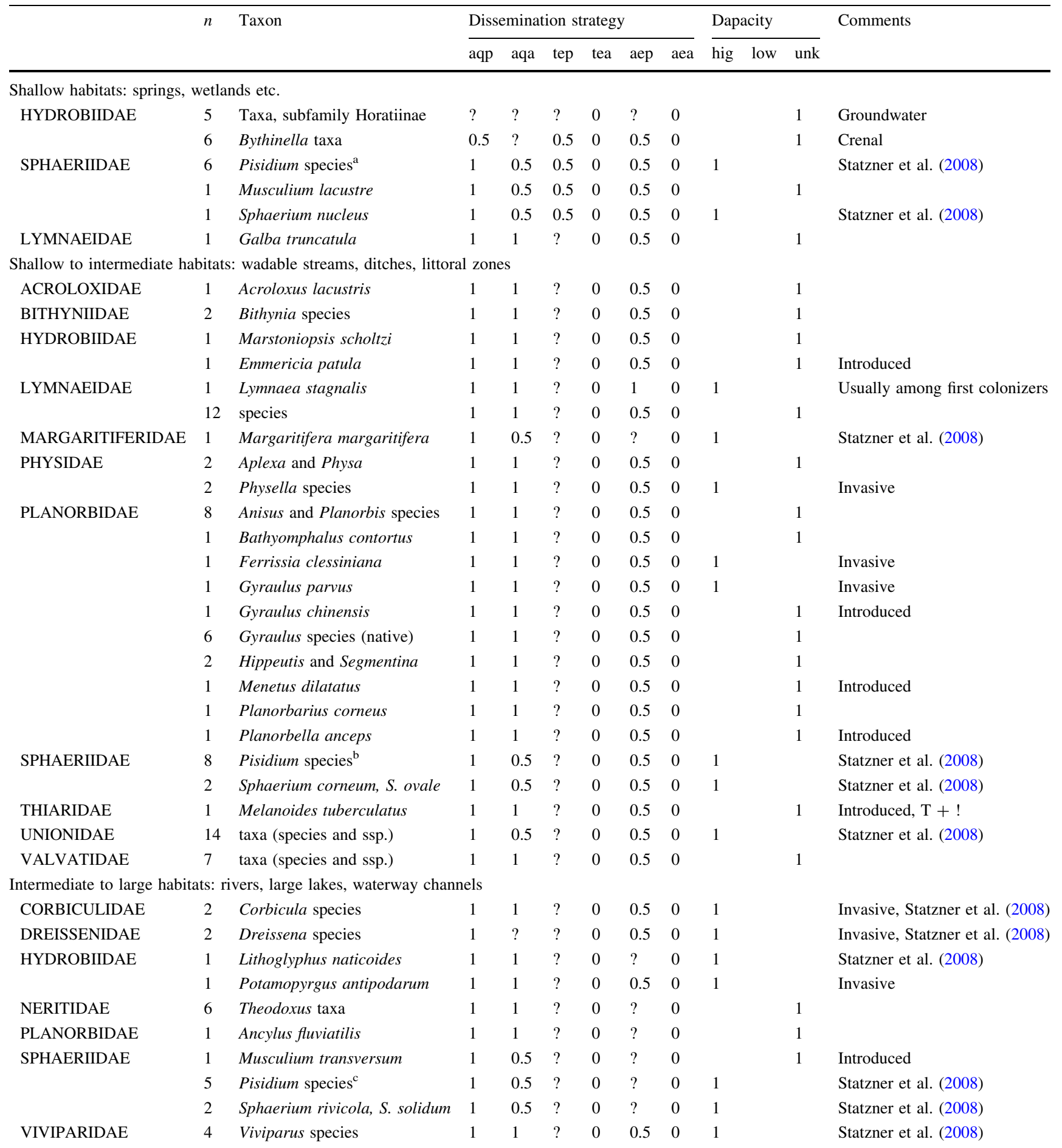

aqp aquatic, passive; aqa aquatic, active; tep terrestrial, passive; tea terrestrial, active; aep aerial, passive; aea aerial, active; hig high; unk unknown. 0 does not apply; 0.5 probability low, or, if active, only at low speed; 1 applies; ? needs further clarification; $T+$ high temperature demand

${ }^{a}$ Pisidium casertanum casertanum, Pisidium globulare, Pisidium obtusale, Pisidium personatum, Pisidium pseudosphaerium, Pisidium subtruncatum

${ }^{\mathrm{b}}$ Pisidium conventus, Pisidium hibernicum, Pisidium lilljeborgii, Pisidium milium, Pisidium moitessierianum, Pisidium nitidum, Pisidium pulchellum, Pisidium tenuilineatum;

${ }^{\mathrm{c}}$ Pisidium amnicum, Pisidium casertanum ponderosum, Pisidium crassum, Pisidium henslowanum, Pisidium supinum 
The values in Table 3 provide estimates that are open to (regionalised) fine tuning once the relative importance of the dispersal strategies of native taxa has been studied in detail. As a general pattern, the main pathways of dispersal are habitat specific (Table 3): the probability of encountering terrestrial vectors can be assumed to decrease from the interface between aquatic and terrestrial habitats to deep water, and contact with waterfowl occurs predominantly in the littoral zone of larger water bodies. Still, the use of some strategies by some species is unclear. For example, is aerial dispersal a factor for spreading of $\mathrm{Pi}$ sidium species that live in large rivers and lakes and if so, under which circumstances do these species meet potential vectors? Also, are there terrestrial vectors for littoral snail species?

\section{Future efforts}

Our review illustrates that preferences for study of Bivalvia, Prosobranchia or Pulmonata have resulted in a lack of sound knowledge about phylogenetic constraints on active dispersal ability (compare Fig. 1). Laboratory experiments are needed, and there is certainly a need for vigorous field studies and in-stream experiments under different environmental conditions, including capture-mark-recapture studies with physical labels or stable isotopes. It may be highly beneficial to cover several higher taxa using the same study approach. As only a subset of all taxa can be studied, it seems best to relate dispersal distances and probabilities to traits such as ability for aestivation, reproductive strategy, and clutch size in a way similar to the approach to estimating invasibility that was used by Statzner et al. (2008).

Passive dispersal is the main long-range dissemination strategy of the Mollusca. Our ability to assessment dispersal capacities is constrained, however, and attempts to quantify passive dispersal have been restricted to invasive bivalves and to anthropogenic vectors such as ships. The suitability and capacity of natural vectors to connect populations along streams and across catchments, and the role of mollusc density and behaviour versus vector density have not been analysed. Because of uncertainties concerning the source of laterally spreading individuals and the sporadic nature of reports on lateral dispersal, an assessment of distance-related probabilities of reaching other streams within or across catchments is hardly possible. Genetic surveys, e.g., with microsatellite markers, can help elucidate the distance at which genetic exchange occurs along both the longitudinal and lateral axes.

Our review suggests that populations usually need to occur within the same stream, probably at a distance of $<3 \mathrm{~km}$, to allow population mixing and successful re-colonisation of restored stream sections within 3-10 years.
Hence, the "Field of Dreams Hypothesis", stating that if habitats are restored, they will be re-colonised by target species may not be rejected per se. However, "habitat" needs to be understood as the spatio-temporal setting of structural and physicochemical properties along with the integration of the restoration site in the landscape in a topographic (geomorphology, land use) sense and in terms of population exchange. Also, expectations concerning the time frame for re-colonisation should not be too narrow. We hypothesise that widely distributed euryecious or invasive species that are already present in a catchment have a higher probability of colonising newly created habitats than rare or patchily distributed species that need to disperse laterally over the terrestrial matrix. Lowlands may have a higher lateral connectivity than do mountainous areas (Hughes 2007), but this fact does not imply that rare species can return more easily. It thus may be necessary to initiate aided migration, provided that the physicochemical and structural properties of the restored location meet the demands of target species.

The results presented in this review indicate that active dispersal capacity is insufficient to follow the projected velocity of climate change. For example, the average velocity of the isotherms is assumed to be $0.35 \mathrm{~km}$ per year in the temperate zone, with local speeds of up to $10 \mathrm{~km}$ per year (Loarie et al. 2009). Isotherms will generally move laterally, not longitudinally, over many rivers and catchments. Consequently, molluscs will depend strongly on passive dispersal. To define species distribution models (SDMs) that include genuine, realistic dispersal kernels, a joint effort is needed to quantify lateral dispersal probabilities from physiological studies on survival under terrestrial conditions, from indications of past dispersal probabilities based on population genetics, and from assessments of the suitability and behaviour of vectors under past, recent and future environmental scenarios.

Acknowledgments This work was financially supported by the research funding programme "LOEWE-Landes-Offensive zur Entwicklung Wissenschaftlich-ökonomischer Exzellenz" of Hesse's Ministry of Higher Education, Research, and the Arts. We also would like to thank two anonymous reviewers for their helpful comments.

Open Access This article is distributed under the terms of the Creative Commons Attribution Noncommercial License which permits any noncommercial use, distribution, and reproduction in any medium, provided the original author(s) and source are credited.

\section{References}

Aarnio K, Bonsdorff E (1997) Passing the gut of juvenile flounder, Platichthys flesus: Differential survival of zoobenthic prey species. Marine Biol 129:11-14 
Ackerman JD, Sim B, Nichols SJ (1994) A review of the early life history of zebra mussels (Dreissena polymorpha): comparisons with marine bivalves. Can J Zool 72:1169-1179

Adam W (1942) Sur la répartition et la biologie de Hydrobia jenkinsi Smith en Belgique. Bull Musée R Hist Nat Belg 18:1-18

Allen DC, Vaughn CC (2009) Burrowing behavior of freshwater mussels in experimentally manipulated communities. J North Am Benthol Soc 28:93-100

Amyot J-P, Downing JA (1998) Locomotion in Elliptio complanata (Mollusca: Bivalvia): a reproductive function? Freshw Biol 39:351-358

Beran L (2006a) Spreading expansion of Corbicula fluminea (Mollusca: Bivalvia) in the Czech Republic. Heldia 6:187-192

Beran L (2006b) Unintentional introduction of aquatic molluscs from Poland to Prague (Czech Republic). Malac Bohemoslov 5:6-9

bij de Vaate A (2010) Some evidence for ballast water transport being the vector of the quagga mussel (Dreissena rostriformis bugensis Andrusov, 1897) introduction into Western Europe and subsequent upstream dispersal in the River Rhine. Aquatic Invasions 5:207-209

Bilton DT, Freeland JR, Okamura B (2001) Dispersal in freshwater invertebrates. Annu Rev Ecol Syst 32:159-181

Blanco JF, Scatena FN (2005) Floods, habitat hydraulics and upstream migration of Neritina virginea (Gastropoda: Neritidae) in northeastern Puerto Rico. Caribb J Sci 41:55-74

Boag DA (1986) Dispersal in pond snails: potential role of waterfowl. Can J Zool 64:904-909

Bobeldyk AM, Bossenbroek JM, Evans-White MA, Lodge DM, Lamberti GA (2005) Secondary spread of zebra mussels (Dreissena polymorpha) in coupled lake-stream systems. Ecoscience 12:339-346

Bohonak AJ, Jenkins DG (2003) Ecological and evolutionary significance of dispersal by freshwater invertebrates. Ecol Lett 6:783-796

Bondesen P, Kaiser EW (1949) Hydrobia (Potamopyrgus) jenkinsi (Smith) in Denmark illustrated by its ecology. Oikos 1:252-281

Bovbjerg RV (1952) Ecological aspects of dispersal of the snail Campeloma decisum. Ecology 33:169-176

Brown RJ (2007) Freshwater mollusks survive fish gut passage. Arctic 60:124-128

Buchan LAJ, Padilla DK (1999) Estimating the probability of longdistance overland dispersal of invading aquatic species. Ecol Appl 9:254-265

Byrne RA, McMahon RF, Dietz TH (1988) Temperature and relative humidity effects on aerial exposure tolerance in the freshwater bivalve Corbicula fluminea. Biol Bull 175:253-260

Carlton JT (1993) Dispersal mechanisms of the zebra mussel (Dreissena polymorpha). In: Nalepa TF, Schloesser DW (eds) Zebra Mussels: Biology, Impacts and Control. Lewis Publishers, Ann Arbor, Michigan, pp 677-697

Cleven E-J, Frenzel P (1993) Population dynamics and production of Dreissena polymorpha (Pallas) in River Seerhein, the outlet of Lake Constance (Obersee). Arch Hydrobiol 127:395-407

Cordellier M, Pfenninger M (2009) Inferring the past to predict the future: climate modelling predictions and phylogeography for the freshwater gastropod Radix balthica (Pulmonata, Basommatophora). Mol Ecol 18:534-544

Cowie RH, Holland BS (2006) Dispersal is fundamental to biogeography and the evolution of biodiversity on oceanic islands. J Biogeogr 33:193-198

Darby PC, Bennetts RE, Miller SJ, Franklin Percival H (2002) Movements of Florida Apple Snails in relation to water levels and drying events. Wetlands 22:489-498

Davis DS, Gilhen J (1982) An observation of the transportation of pea clams, Pisidium adamsi, by Blue-Spotted Salamanders, Ambystoma laterale. Can field-naturalist 96:213-214
Darwin C (1859) The origin of species. John Murray, London

Darwin C (1878) Transplantation of shells. Nature 448:120-121

Darwin C (1882) On the dispersal of freshwater bivalves. Nature 649:529-530

Dean J, Edds D, Gillette D, Howard J, Sherraden S, Tiemann J (2002) Effects of lowhead dams on freshwater mussels in the Neosho River, Kansas. Trans Kansas Acad Sci 105232-240

Dubois C (1995) Biologie et démo-écologie d'une espèce invasive, Corbicula fluminea (Mollusca : bivalvia) originaire d'Asie: étude in situ (canal latéral à la Garonne, France) et en canal expérimental. Thèse de Doctorat, Univ. Paul Sabatier, Toulouse, $169 \mathrm{p}$

Elderkin CL, Christian AD, Vaughn CC, Metcalfe-Smith JL, Berg DJ (2007) Population genetics of the freshwater mussel, Amblema plicata (Say 1817) (Bivalvia: Unionidae): Evidence of high dispersal and post-glacial colonization. Conserv Genetics $8: 355-372$

Euro-limpacs Consortium (2009) Taxa and autecology database for freshwater organisms. Euro-limpacs project (contract no. GOCECT-2003-505540), Workpackage 7-Indicators of ecosystem health, Task 4, www.freshwaterecology.info (version 4.0, viewed 06.09.2010)

Gelembiuk GW, May GE, Lee CE (2006) Phylogeography and systematics of zebra mussels and related species. Mol Ecol 15:1033-1050

Gittenberger E, Groenenberg DS, Kokshoorn B, Preece RC (2006) Biogeography: molecular trails from hitch-hiking snails. Nature 439:409

Grabow K, Martens A (1995) Vorkommen von Corbicula fluminea (O. MÜLLER 1774) und $C$. ,fluminalis" (O. MÜLLER 1774) im östlichen Mittellandkanal (Bivalvia: Corbiculidae). Mitt dtsch Malakozool Ges 56(57):19-23

Green AJ, Figuerola J (2005) Recent advances in the study of longdistance dispersal of aquatic invertebrates via birds. Diversity Distrib. 11:149-156

Groh K, Fuchs H (1988) Zum Vorkommen der Quellschnecke Bythinella dunkeri (Frauenfeld 1857) in der Eifel. Mitt dtsch malakozool Ges 43:19-27

Gutiérrez-Gregoric DE, Vogler RE (2010) Riesgo de establecimiento del gasterópodo dulceacuícola invasor Melanoides tuberculatus (Thiaridae) en el Río de la Plata (Argentina-Uruguay). Revista Mexicana de Biodiversidad 81:573-577

Haynes A, Taylor BJR, Varley ME (1985) The influence of the mobility of Potamopyrgus jenkinsi (Smith E.A.) (Prosobranchia: Hydrobiidae) on its spread. Arch Hydrobiol 103:497508

Hoffman AL, Olden JD, Monroe JB, LeRoy Poff N, Wellnitz T, Wiens JA (2006) Current velocity and habitat patchiness shape stream herbivore movement. Oikos 115:358-368

Holeck KT, Mills EL, MacIsaac HJ, Dochoda MR, Colautti RI, Ricciardi A (2004) Bridging troubled waters: Biological invasions, transoceanic shipping, and the Laurentian Great Lakes. Bioscience 54:919-929

Holomuzki JR, Biggs BJF (1999) Distributional responses to flow disturbance by a stream-dwelling snail. Oikos 87:36-47

Horvath TG, Lamberti G (1997) Drifting macrophytes as a mechanism for zebra mussel (Dreissena polymorpha) invasion of lakeoutlet streams. Am Midl Nat 138:29-36

Hughes JM (2007) Constraints on recovery: using molecular methods to study connectivity of aquatic biota in rivers and streams. Freshw Biol 52:616-631

Huryn AD, Denny MW (1997) A biomechanical hypothesis explaining upstream movements by the freshwater snail Elimia. Funct Ecol 11:472-483

Hutchinson L (1947) Analysis of the activity of the freshwater snail Viviparus malleatus (Reeve). Ecology 28:335-345 
IKSR (2002) Das Makrozoobenthos des Rheins 2000. Report Nr. 128-d.doc. Koblenz

Johnson LE, Carlton JT (1996) Post-establishment spread in largescale invasions dispersal mechanisms of the zebra mussel Dreissena polymorpha. Ecology 77:1686-1690

Johnson CW (1904) Ancyli adhering to water beetles. Nautilus $17: 120$

Karataev AY, Burlakova LE (1995) The role of Dreissena in lake ecosystems. Russ J Ecol 26:207-211

Karatayev AY, Boltovskoy D, Padilla DK, Burlakova LE (2007) The invasive bivalves Dreissena polymorpha and Limnoperna fortunei: parallels, contrasts, potential spread and invasion impacts. J Shellfish Res 26:205-213

Kobialka H, Schwer H, Kappes H (2009) Rote Liste der gefährdeten Schnecken und Muscheln (Mollusca: Gastropoda et Bivalvia) in Nordrhein-Westfalen. 3. Fassung 2009. Mitt dtsch Malakozool Ges 82:3-30

Kraft CE, Johnson LE (2000) Regional differences in rates and patterns of North American inland lake invasions by zebra mussels (Dreissena polymorpha). Can J Fish Aquat Sci 57:993-1001

Kwet A (1995) Erdkröten (Bufo bufo) als Transportwirte von Kugelmuscheln (Sphaerium corneum). Salamandra 31:61-64

Leuven RSEW, van der Velde G, Baijens I, Snijders J, van der Zwart C, Lenders HJR, bij de Vaate A (2009) The river Rhine: a global highway for dispersal of aquatic invasive species. Biol Invasions 11:1989-2008

Liu H-P, Hershler R (2009) Genetic diversity and population structure of the threatened Bliss Rapids snail (Taylorconcha serpenticola). Freshw Biol 54:1285-1299

Loarie SR, Duffy PB, Hamilton H, Asner GP, Field CB, Ackerly DD (2009) The velocity of climate change. Nature 462:1052-1055

Lucy FE, Minchin D, Boelens R (2008) From lakes to rivers: downstream larval distribution of Dreissena polymorpha in Irish river basins. Aquatic Invasions 3:297-304

Lyons J, Kanehl P (2002) Seasonal movements of smallmouth bass in streams. In: Philipp DP, Ridgeway MS (eds) Black bass: Ecology, conservation, and management, symposium 31. American Fisheries Society, Bethesda, Maryland, pp 149-160

Mackie GL (1979) Dispersal mechanisms in Sphaeriidae (Mollusca: Bivalvia). Bull Am Malacol Union 45:17-21

MacRae M, Lepitzki DAW (1994) Population estimation of the snail Bithynia tentaculata (Gastropoda: Prosobranchia) using markrecapture and the examination of snail movement in pools. Can field-naturalist 108:58-66

Madsen H, Frandsen F (1989) The spread of freshwater snails including those of medical and veterinary importance. Acta Tropica 46:139-146

Maguire B Jr (1963) The passive dispersal of small aquatic organisms and their colonization of isolated bodies of water. Ecol Monogr 33:161-185

Malone CR (1965) Dispersal of aquatic gastropods via the intestinal tract of water birds. Nautilus 78:135-139

Mayer S, Rander A, Grabow K, Martens A (2009) Binnenfrachtschiffe als Vektoren der Quagga-Muschel Dreissena rostriformis bugensis (Andrusov) im Rhein (Bivalvia: Dreissenidae). Lauterbornia 67:63-67

Miller MP, Weigel DE, Mock KE (2006) Patterns of genetic structure in the endangered aquatic gastropod Valvata utahensis (Mollusca: Valvatidae) at small and large spatial scales. Freshw Biol 51:2362-2375

Morton B (1970) The evolution of the heteromyarian condition in the Dreissenacea (Bivalvia). Palaeontology 13:563-572

Müller K (1954) Investigations on the organic drift in north Swedish streams. Rep Inst Freshwat Res Drottningholm 35:532-537
Neves RJ, Bogan AE, Williams JD, Ahlstedt SA, Hartfield PW (1997) Status of aquatic mollusks in the southeastern United States: a downward spiral of diversity. In: Benz GW, Collins DE (eds) Aquatic fauna in peril: the southeastern perspective. Southeast Aquatic Research Institute, Lenz Design and Communications, Decatur, Georgia, pp 43-86

Orlova MI, Muirhead JR, Antonov PI, Shcherbina GK, Starobogatov YI, Biochino GI, Therriault TW, MacIsaac HJ (2004) Range expansion of quagga mussels Dreissena rostriformis bugensis in the Volga River and Caspian Sea basin. Aquatic Ecol 38:561-573

Pathy DA, Mackie GL (1993) Comparative shell morphology of Dreissena polymorpha, Mytilopsis leucophaeata, and the "quagga" mussel (Bivalvia: Dreissenidae) in North America. Can J Zool 71:1012-1023

Peredo S, Parada E, Valdebenito I, Peredo M (2006) Effect of aerial exposure on physiological condition and survival of Diplodon chilensis (Bivalvia: Hyriidae) during translocation. Malacologia 49:217-221

Prezant RS, Chalermwat K (1984) Flotation of the bivalve Corbicula fluminea as a means of dispersal. Science 225:1491-1493

Pyron M, Covich AP (2003) Migration patterns, densities, and growth of Neritina punctulata snails in Rio Espiritu Santo and Rio Mameyes, northeastern Puerto Rico. Caribb J Sci 39:338-347

Rahel FJ (2002) Homogenization of freshwater faunas. Ann Rev Ecol Syst 33:291-315

Rees WJ (1965) The aerial dispersal of Mollusca. Proc Malacol Soc London 36:269-282

Ribi G (1986) Within-lake dispersal of the prosobranch snails, Viviparus ater and Potamopyrgus jenkinsi. Oecologia 69:60-63

Ribi G, Arter H (1986) Sex related difference of movement speed in the freshwater snail Viviparus ater. J Moll Stud 52:91-96

Ricciardi A, Serrouya R, Whoriskey FG (1995) Aerial exposure tolerance of zebra and quagga mussels (Bivalvia: Dreissenidae): implications for overland dispersal. Can J Fish Aquat Sci $52: 470-477$

Roscoe EJ (1955) Aquatic snails found attached to feathers of Whitefaced Glossy Ibis. Wilson Bull 67:66

Saarinen M, Taskinen J (2003) Burrowing and crawling behaviour of three species of Unionidae in Finland. J Moll Stud 69:81-86

Schneider DW, Frost TM (1986) Massive upstream migrations by a tropical freshwater neritid snail. Hydrobiologia 137:153-157

Schneider DW, Lyons J (1993) Dynamics of upstream migration in two species of tropical freshwater snails. J N Am Benthol Soc 12:3-16

Schwalb AN, Pusch MT (2007) Horizontal and vertical movements of unionid mussels in a lowland river. $\mathrm{J} \mathrm{N}$ Am Benthol Soc 26:261-272

Shelford VE (1914) An experimental study of the behavior agreement among the animals of an animal community. Biol Bull 26:294-315

Sigurdsson JB, Titman CW, Davies PA (1976) The dispersal of young post larval bivalve molluscs by byssus threads. Nature 262:386-387

Snider SB, Gilliam JF (2008) Movement ecology: size-specific behavioral response of an invasive snail to food availability. Ecology 89:1961-1971

Sprung M (1989) Field and laboratory observations of Dreissena polymorpha larvae: abundance, growth, mortality and food demands. Arch Hydrobiol 115:537-561

Sprung M (1993) The other life: an account of present knowledge of the larval phase of Dreissena polymorpha. In: Nalepa TF, Schloesser DW (eds) Zebra Mussels: Biology. Impacts and Control. Lewis Publishers, Boca Raton, FL, pp 39-53

Städler T, Frye M, Neiman M, Lively CM (2005) Mitochondrial haplotypes and the New Zealand origin of clonal European 
Potamopyrgus, an invasive aquatic snail. Mol Ecol 14:2465-2473

Statzner B, Bonada N, Dolédec S (2008) Biological attributes discriminating invasive from native European stream macroinvertebrates. Biol Invasions 10:517-530

Stevens VM, Pavoine S, Baguette M (2010) Variation within and between closely related species uncovers high intra-specific variability in dispersal. PLoS ONE 5(6): e11123. doi: 10.1371/journal.pone.0011123

Stewart TW (2007) Measuring animal movements in a natural ecosystem: A mark-recapture investigation using stream-dwelling snails. Am Biol Teacher 69:6-16

Strayer DL (1991) Projected distribution of the zebra mussel, Dreissena polymorpha, in North America. Can J Fish Aquat Sci 48:1389-1395

Taylor DW (1988) Aspects of freshwater mollusc ecological biogeography. Palaeogeogr Palaeoclimat Palaeoecol 62:511-576

Therriault TW, Orlova MI, Docker MF, MacIsaac HJ, Heath DD (2005) Invasion genetics of a freshwater mussel (Dreissena rostriformis bugensis) in eastern Europe: high gene flow and multiple introductions. Heredity 95:16-23

Voelz NJ, McArthur JV, Rader RB (1998) Upstream mobility of the Asiatic Clam Corbicula fluminea: Identifying potential dispersal agents. J Freshw Ecol 13:39-45

Waller DL, Rach JJ, Cope WG, Miller GA (1995) Effects of handling and aerial expositure on the survival of unionid mussels. J Freshw Ecol 10:199-207
Watters GT (1996) Small dams as barriers to freshwater mussels (Bivalvia, Unionoida) and their hosts. Biol Conserv 75:79-85

Wesselingh FP, Cadée GC, Renema W (1999) Flying high: on the airborne dispersal of aquatic organisms as illustrated by the distribution histories of the gastropod genera Tryonia and Planorbarius. Geol Mijnb 78:165-174

Wilson AB, Naish K-A, Boulding EG (1999) Multiple dispersal strategies of the invasive quagga mussel (Dreissena bugensis) as revealed by microsatellite analysis. Can J Fish Aquat Sci $56: 2248-2261$

Wood LR, Griffiths RA, Groh K, Engel E, Schley L (2008) Interactions between freshwater mussels and newts: a novel form of parasitism? Amphibia-Reptilia 29:457-462

Worthington Wilmer J, Elkin C, Wilcox C, Murray L, Niejalke D, Possingham H (2008) The influence of multiple dispersal mechanisms and landscape structure on population clustering and connectivity in fragmented artesian spring snail populations. Mol Ecol 17:3733-3751

ZhulidovAV Zhulidov DA, Pavlov DF, Nalepa TF, Gurtovaya TY (2005) Expansion of the invasive bivalve mollusk Dreissena bugensis (quagga mussel) in the Don and Volga River Basins: Revisions based on archived specimens. Ecohydrol Hydrobiol 5:127-133 